\title{
MENYIAPKAN SDM UNGGUL DAN RELIGIUS MELALUI IKHTIAR KEGIATAN KEAGAMAAN DI DESA JONJO KABUPATEN GOWA
}

\author{
Askar Patahuddin \\ Sekolah Tinggil Ilmu Islam dan Bahasa Arab (STIBA) Makassar \\ askarfatahuddin@stiba.ac.id \\ Jujuri Perdamaian Dunia \\ Sekolah Tinggil Ilmu Islam dan Bahasa Arab (STIBA) Makassar \\ jujuri@stiba.ac.id
}

\begin{abstract}
Keywords :
ABSTRACT

Jonjo Village, KKN STIBA, Excellent human resources, Religious

Creating excellent and religious human resources is a provision for building a civil society. This community service aims to prepare excellent and religious human resources in Jonjo village through various religious programs in the village. Community service was conducted by ten students of STIBA Makassar. The effort to create an excellent and religious Jonjo village community is through activities of 1) dirosa; 2) teaching tahsin; 3) teaching $T K A / T P A$; 4) evening and dawn brief preaching; 5) Friday sermon; 6) training for burial ritual; 7) festival of pious children; 8) tabligh akbar. In general, the activities of KKN students of STIBA Makassar students in Jonjo Village went well. All work programs implemented have been welcomed enthusiastically by the government and society. The obstacle that becomes a challenge in the process of implementing work programs was that the majority of community activities work as farmers in rice fields, making students need to manage the time for conducting more activities at night so that the community can involve.
\end{abstract}

Kata kunci :

Desa Jonjo, KKN STIBA, SDM unggul, Religius

\begin{abstract}
Menciptakan sumber daya manusia yang unggul dan religious merupakan bekal dalam mewujudkan masyarakat madani. Tujuan pengabdian masyarakat ini adalah untuk menyiapkan SDM unggul dan religius di desa Jonjo melalui berbagai program keagamaan di desa. Pengabdian masyarakat dilaksanakan oleh mahasiwa STIBA Makassar yang berjumlah sepuluh orang. Usaha terwujudnya masyarakat desa Jonjo yang unggul dan religius melalui kegiatan 1) dirosa; 2) pengajaran tahsin; 3) pengajaran TKA/TPA; 4) kultum magrib dan subuh; 5) khutbah jum'at; 6) pelatihan penyelenggaraan jenazah; 7) festival anak saleh; 8) tabligh akbar. Secara umum kegiatan KKN Mahasiswa STIBA Makassar angkatan ke III di Desa Jonjo berjalan dengan baik dan lancar. Seluruh program kerja yang dilaksanakan disambut baik dan antusias oleh pemerintah dan masyarakat. Adapun kendala yang menjadi tantangan dalam proses pelaksanaan program kerja adalah aktivitas masyarakat yang mayoritas bekerja sebagai petani di ladang persawahan membuat mahasiswa perlu mengatur waktu pelaksanaan kegiatan lebih banyak dilaksanakan pada malam hari agar masyarakat dapat terlibat lebih maksimal.
\end{abstract}




\section{PENDAHULUAN}

\section{A. Profil Desa Jonjo}

Secara historis kata Jonjo berasal dari Bahasa Makassar " Pajonjo " yang mengandung 2 arti "menyuruh" atau "memberi. Desa Jonjo merupakan salah satu Desa dari Lima (5) Desa yang ada di Kecamatan Parigi Kabupaten Gowa. Desa Jonjo terdiri atas 4 (empat) dusun yakni Dusun Jonjo, Bukit Parigi, Baliti, dan Laloasa.

\section{Keadaan Geografis, Demografis, dan Topografis Desa Jonjo}

Desa Jonjo secara geografis berada di ketinggian antara 500-800 dpl (diatas permukaan laut). Dengan keadaan curah hujan rata-rata dalam pertahun antara 32-35 mm per tahun yang berkisar 135 hari s/d 160 hari dengan suhu rata-rata pertahun adalah 15 s/d $20{ }^{\circ}$ C. Secara administrasi Desa Jonjo terletak di Wilayah Kecamatan Parigi Kabupaten Gowa, yang merupakan satu dari 5 Desa di Wilayah kecamatan Parigi secara administrasi dibatasi oleh wilayah Kabupaten dan Kecamatan serta Kelurahan tetangga.

Secara demografi, Desa Jonjo berbetasan dengan berbagai desa lainya yang berada di wilayah Kecamatan Parigi maupun dengan Desa dari Kecamatan lainnya. Secara rinci Desa Jonjo pada setiap penjuru mata angina diuraikan sebagai berikut: Di sebelah utara, Desa Jonjo berbatasan dengan Desa Parigi, Kecamatan Tinggimoncong. Di sebelah Selatan, Desa Jonjo berbatasan dengan Desa Sicini, Kecamatan Parigi. Di sebelah Barat Desa Jonjo berbatasan dengan Desa Tamalatea, Kecamatan Manuju dan Desa Jenebatu Kecamatan, Bungaya. Terakhir, di sebelah timur, Desa Jonjo berbatasan dengan desa Majannang yang masih berada di wilayah Kecamatan Parigi.

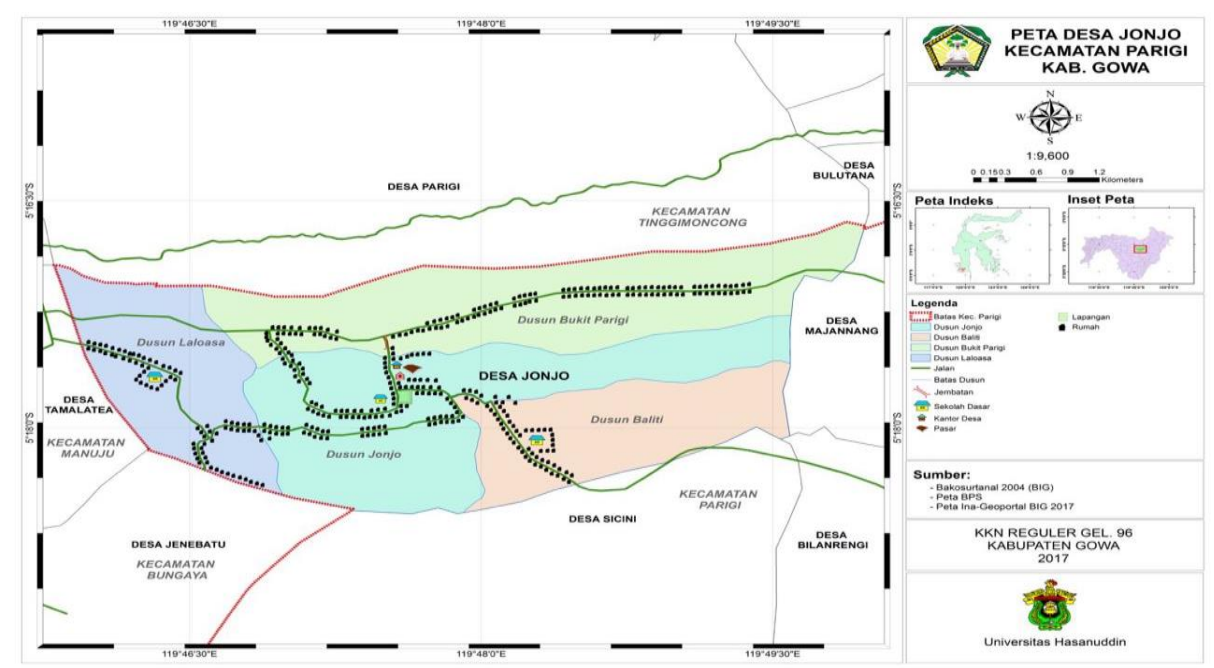

Gambar 1. Peta Desa Jonjo Kec. Parigi

Desa Jonjo mempunyai kondisi daerah yang berada di dataran tinggi, sehingga tanahnya sangat subur untuk lahan pertanian sawah dan kebun sangat cocok untuk palawija dan tanaman jangka panjang. 
WAHATUL MUJTAMA': Jurnal Pengabdian Masyarakat

Vol. 1, No. 2 (2020) : Hal. 116-128

Website: https://journal.stiba.ac.id

\section{Bahasa dan Sistem Pengetahuan}

Sebagaimana umumnya di kabupaten Gowa, bahasa yang digunakan pada umumnya oleh masyarakat desa adalah bahasa daerah yaitu Bahasa Makassar, Bahasa Indonesia hanya dipergunakan pada pertemuan-pertemuan resmi seperti di sekolah, perkantoran dan lain sebagainya, adapun bahasa sehari-hari di rumah dan di tempattempat umum menggunakan bahasa daerah.

\section{Sistem Kemasyarakatan/ Organisasi Sosial}

Desa Jonjo dipimpin oleh kepala desa yang dipilih secara langsung oleh masyarakat melalui pemilihan kepala desa, walaupun belum berstatus kelurahan namun Jonjo merupakan pusat pemerintahan kecamatan, hampir semua fasilitas kecamatan seperti Kantor Camat, Kantor KUA, Puskesmas, Majid Jami’ dan lain-lain. Kepala Desa Jonjo membawahi 3 (tiga) kepala dusun dari Dusun Nirannuang, Dusun Longka, dan Dusun Sironjong.

\section{Sistem Peralatan Hidup dan Teknologi}

Kehidupan di Jonjo cukup maju dibanding beberapa desa di kecamatan Parigi karena merupakan desa pertama yang dijumpai ketika masuk Kecamatan ini, hadirnya listrik hampir disetiap rumah warga cukup berpengaruh meningkatkan budaya hidup dan teknologi masyarakat parigi. Peralatan rumah tangga sudah terbilang moderen, begitupula dengan peralatan pertanian dan perkebunan sebagai mata pencaharian utama masyarakat Jonjo sudah menggunaakan teknologi terbaru. Sistem transportasi umum jarak jauh menggunakan tranportasi roda empat, yang memfasilitasi masyarakat disaat bepergian ke kota terdekat seperti Kotamadya Makassar dan Kota Sungguminasa, adapun perjalanan jarak dekat antar desa atau antar kecamatan, masyarakat mengandalkan kendaraan pribadi baik roda dua maupun roda empat.

\section{Sistem Mata Pencaharian Hidup/ Ekonomi}

Masyarakat Kecamatan Parigi umumnya berprofesi sebagai petani utamanya pertanian sawah atau tanaman pangan lainnya seperti jagung dan kedelai, sedangkan sektor non pertanian terutama bergerak pada lapangan usaha perdagangan besar dan eceran. Letaknya pada pusat kecamatan Parigi cukup mengundang minat pedagang untuk masuk ke pasar Jonjo, bahkan sebagian pedagang membuka kios-kios dagangan dipinggiran jalan poros seperti warung makan, toko ATK, toko sembako, toko baju dan lain sebagainya. Selain petani/peternak dan pedagang sebagian masyarakat desa Jonjo ada juga yang bergelut dibidang pemerintahan dan berstatus PNS, sebagian lainnya berprofesi sebagai tukang, sopir, buruh tani, buruh bangunan, tukang kayu dan tukang batu, guru honor. Keragaman mata pencaharian di Desa Jonjo menjadikan perekonomian menjadi dinamis dan berkembang dari hari ke hari. 
WAHATUL MUJTAMA': Jurnal Pengabdian Masyarakat

Vol. 1, No. 2 (2020) : Hal. 116-128

Website: https://journal.stiba.ac.id

\section{Sistem Religi}

Menurut data statistik Kabupaten Gowa terbaru tahun 2019, jumlah penduduk yang beragama Islam mencapai angka 100\% yaitu sebanyak 2.812, dengan jumlah rumah ibadah 12 Masjid dan 4 Musalla. Aktifitas keagamaan cukup aktif dengan keberadaan Kantor Urusan Agama (KUA) tingkat kecamatan. Keberadaan BKPRMI kecamatan parigi di Desa Jonjo cukup menyemarakkan aktifitas belajar mengajar Alquran tingkat anak pada kelompok TK-TPA disetiap Masjid Desa Jonjo, Keberadaan Majelis Taklim Ibu-ibu menambah meriah kehidupan beragama di Desa Jonjo. Namun masih didapati beberapa tradisi-tradisi nenek moyang yang masi dipertahankan oleh sebagian masyarakat seperti tradisi ma'baca-baca.

\section{B. Potensi Lokal Lokasi KKN STIBA Makassar}

Berdasarkan tabulasi data tersebut teridentifikasi di Desa Jonjo jumlah penduduk yang mempunyai mata pencaharian dari jumlah penduduk secara keseluruhan. Kehidupannya tergantung disektor Pertanian, petani 85,34\%. Terban yak kedua adalah sektor Pertukangan dengan $8,08 \%$ dari jumlah total penduduk. Sektor perdagangan menempati urutan ketiga dari hasil presentase sebanyak 2,58 \% dari jumlah penduduk yang mempunyai pekerjaan. Sementara urutan ke empat berada pada sektor jasa dari hasil presentase sebanyak $1,18 \%$ dan yang mempunyai presentase terkecil POLRI 0,03 $\%$ dari jumlah penduduk yang mempunyai pekerjaan.

Dengan demikian dari data tersebut menunjukkan bahwa masyarakat di Desa Jonjo memiliki alternative pekerjaan selain bertani. setidaknya karena wilayah Desa Jonjo memiliki potensi sumber daya alam yang dapat menunjang kelanjutan hidup masyarakat yang bermukim di wilayah tersebut.

\section{Sektor Pertanian dan Perkebunan}

Jenis tanaman yang dibudidayakan pada lahan pertanian seperti padi, kacangkacangan, kedelai yang biasanya ditanam pada lahan sawah, sedangkan untuk lahan kebun selain tanaman diatas juga ditanami tanaman jangka panjang yaitu tanaman jangka panjang. Dari hasil budidaya tanaman tersebut pada umumnya dijadikan sumber makanan pokok dan sebagian dijual ke pasar.

\section{Sektor Peternakan}

Sektor peternakan sudah mulai berkembang di masyarakat seperti peternakan ayam kampung, ayam potong, sapi, kuda. Masyarakat Desa Jonjo masih banyak yang menggunakan sapi untuk membajak lahan pertanian. Pada umumnya masyarakat membuat rumah untuk hewan ternaknya di sekitar rumah bahkan ada yang di kolom rumah, sehingga jika dilihat dari segi kesehatan lingkungan sangat terganggu karena menimbulkan aroma tak sedap terutama pada musim hujan tiba. 
WAHATUL MUJTAMA': Jurnal Pengabdian Masyarakat

Vol. 1, No. 2 (2020) : Hal. 116-128

Website: https://journal.stiba.ac.id

\section{Sektor Jasa}

a) Jasa Pertukangan

Tukang Kayu dan tukang batu pada umumnya keterampilannya dimanfaatkan jika ada pembuatan rumah panggung dan rumah batu. Dari hasil pendapatan tidak banyak membawa perubahan karena memang penghasilan tidaklah menentu. Disamping peralatan yang digunakan dan modal yang masih kurang, sehingga sangat berpengaruh pada hasil kinerjanya. Tukang batu ini biasanya bekerja di luar Desa atau ke Makassar, hanya beberapa saja yang tinggal di Desa karena memang keterampilan ini tidak semua warga membutuhkan tenaganya. Sehingga mereka yang keluar Desa akan kembali jika ada acara keluarga atau hari-hari besar.

b) Jasa Angkutan

Jasa angkutan umum di desa Jonjo sebagian besar didominiasi oleh jasa pelayanan ojek. Ojek ini dimanfaatkan oleh masyarakat dalam dan luar Desa untuk berbagai aktivitas seperti ke pasar dan antar jemput anak sekolah. Jasa angkutan lainnya adalah Sopir mobil angkutan umum dan mobil truk. Pekerjaan ini dilakoni sebanyak 17 orang. Setiap pagi hari mereka berkeliling mencari penumpang untuk diangkut ke kota.

c) Jasa Layanan Publik dan Usaha Jual Beli

Di Desa Jonjo juga sudah mulai berkembang usaha jual beli kebutuhan pokok biasanya dilakukan di pasar baik yang ada di Desa sendiri maupun diluar Desa bahkan diluar kecamatan. Ada juga yang membuat kios di depan rumah untuk menjual kebutuhan sehari-hari rumah tangga.

\section{PEMBAHASAN}

\section{A. Pengembangan SDM Masyarakat dan Konsep Manusia Unggul}

Manusia merupakan sumber daya terpenting dan paling strategis dalam perjalanan roda kehidupan dunia diberbagai $\operatorname{lini}^{1}$, baik dalam bentuk korporasi, instit usi, organisasi hingga bermasyarakat dan berbangsa. Tidak ada satupun pandangan keagamaan, ideologi, maupun falsafiah, yang menafikan kedudukan manusia. Oleh karena itu, segala sesuatu yang berikaitan dengan upaya untuk meningkatkan kualitas manusia menjadi penting untuk diupayakan. Manusia sebagai makhluk ciptaan sang khalik telah dibekali dengan berbagai potensi dan kompetensi yang merupakan anugerah yang perlu untuk dioptimalkan dengan baik. Optimalisasi berbagai potensi dan kompetensi tersebut dikondisikan melalui berbagai program dan kegiatan diantaranya pada lembaga pendidikan, lingkungan sosial, dan keluarga. Secara umum berbagai pengkondisian tersebut berfungsi untuk mengembangkan potensi yang dimiliki agar

\footnotetext{
${ }^{1}$ Tjutju Yuniarsih and Suwatno, Manajemen Sumberdaya Manusia (Teori, Aplikasi Dan Isu Penelitian) (Bandung: Alfabeta, 2013). h. 8
} 
dapat berkembang secara aktual dan meberikan manfaat untuk diri dan orang lain sebagai perwujudan pengambaan kepada Sang Pencipta. ${ }^{2}$

Kemajuan suatu bangsa juga tidak akan pernah lepas dari kualitas sumber daya manusia yang ada di dalamnya serta seluruh aspek turunan dalam pengelolaan kehidupan bermasyarakat dan berbangsa. Oleh karena itu, berbagai upaya peningkatan kualitas manusia perlu untk mendapatkan perhatian yang serius ${ }^{3}$. Upaya peningkatan kualitas tersebut dapat dilakukan dalam berbagai aspek dan konteks, seperti: pendidikan, sosial, ekonomi, budaya, hukum, dll. Perlu disadari bahwa tanpa SDM berkualitas, apapun visi, misi, target, tujuan, workplanning yang telah dipersiapkan secara baik dan ideal, tidak akan efektif dan fungsional. Suatu organisasi, perusahaan, bangsa, agama, bahkan peradaban yang maju dapat dipastikan memiliki SDM berkualitas, inovatif dan produktif. ${ }^{4}$ Pengembangan Sumber Daya Manusia (selanjutnya disebut PSDM) menjadi salah satu bagian yang layak untuk mendapatkan perhatian dalam roda perjalanan kehidupan bermasyarakat dan berbangsa.

Dalam konteks falsafah pengembangan SDM, dikenal istilah Ubermensch yang diperkenalkan oleh Nietzche. Ubermensch menurut Nietzche merupakan seorang superman yang mempunyai kemampuan diatas manusia lainnya secara umum namun lebih kepada kemampuan yang sifatnya individualistic. Keunggulan yang diharapkan dalam pengembangan SDM masyarakat diabad kontemporer adalah keunggulan yang sifatnya partisipatoris. Artinya manusia unggul adalah manusia yang ikut serta secara aktif di dalam persaingan yang sehat untuk mencari yang terbaik. Keunggulan yang dimiliki dan dikembangkan oleh seseorang ditujukan untuk mencapai bukan hanya keuntungan pribadi tetapi keuntungan yang lebih besar karena merupakan pengikut sertaannya didalam suatu masyarakat yang semakin lama semakin berkualitas. ${ }^{5}$

SDM yang unggul diperoleh melalui suatu proses yang berjalan. Oleh karena itu dibutuhkan suatu program yang dilaksanakan dalam bentuk formal maupun nomformal dalam rangka membersiapkan dan mewujudka hadirnya SDM yang unggul. Menurut Tilaar, terdapat tiga tuntutan terhadap SDM bidang pendidikan dalam era globalisasi, yaitu: SDM yang unggul, SDM yang terus belajar, dan SDM yang memiliki nilai-nilai indigeneous dan ketiga hal tersebut akan dicapai melalui program pengembangan SDM. ${ }^{6}$

\footnotetext{
${ }^{2}$ Ibnu Rosidi, "Pengembangan SDM Dalam Pembentukan Karakter Santri Di Lembaga Pengabdian Pada Masyarakat (LPM) Pondok Pesantren Wahid Hasyim Yogyakarta," TA'LIM: Jurnal Studi Pendidikan Islam 1, no. 1 (2018): 106-120. h.109

${ }^{3}$ Iskandar Iskandar and Muhammad Amirullah, "Pelaksanaan Dirasah Qur'aniyah Sebagai Upaya Peningkatan Kualitas Baca Al-Qur'an Di Desa Tukamasea Kabupaten Maros," WAHATUL MUJTAMA': Jurnal Pengabdian Masyarakat 1, no. 1 (2020): 42-53.

${ }^{4}$ Aunur Rofiq, Sumber Daya Manusia Berkualitas Perspektif Nabi Syu'aib Dalam Al-Qur'an (Malang: Lembaga Penelitian dan Pengabdian kepada Masyarakat UIN Maulana Malik Ibrahim, 2011).

${ }^{5}$ Muhammad Satar, "Pengembangan SDM Indonesia Unggul Menghadapi Masyarakat Kompetitif Era Globalisasi," Mimbar: Jurnal Sosial dan Pembangunan 18, no. 4 (2002): 429-442. p.433

${ }^{6}$ Epon Ningrum, "Pengembangan Sumber Daya Manusia Bidang Pendidikan," Jurnal Geografi Gea 9, no. 1 (2009).
} 
Konteks pengembangan kualitas manusia juga sangat erat kaitannya dalam agama Islam. Islam menghendaki manusia berada kualitas kompetensi yang tinggi dan luhur (unggul). Manusia juga telah dikaruniai akal, perasaan, dan tubuh yang sempurna. agar manusia menjadi individu yang dapat mengembangkan diri dan menjadi anggota masyarakat yang berdaya guna sehingga dapat mengembangkan seluruh potensi sumber daya yang dimilikinya. ${ }^{7}$

\section{B. Program Pengembangan SDM Unggul dan Religius di Desa Jonjo}

Kualitas manusia terbaik dalam Islam merujuk pada era saat manusia-manusia terbaik lahir dari proses pendidikan, pembinaan dan pelatihan insan terbaik yaitu Rasulullah. Generasi tersebut adalah generasi di tiga masa awal Islam, Sahabat, tabi'in, dan atbauttabi'in. Allah swt. memerintahkan kita untuk mengikuti generasi terbaik ini dan berjalan diatas jalan yang mereka tempuh serta berperilaku selaras dengan apa yang telah mereka perbuat. ${ }^{8}$ Aspek tauhid menjadi perkara pertama dan utama yang ditanamkan pada SDM terbaik dimasa Rasulullah dan sahabat. Ketauhidan adalah unsur yang pertama dan utama dalam kurikulum pendidikan maupun pelatihan dan pembinaan mereka. Tauhid ini akan memberikan kekuatan jiwa kepada pemiliknya. Dalam proses pendidikan dan Pelatihan, tauhid menjadi unsur pertama dan utama sebelum materi yang lain. Tauhid menjadi fondasi dan dasar pembelajaran.

Pengabdian kepada masyarakat merupakan salah satu implementasi dari Tridharma Perguruan Tinggi. Kegiatan tersebut menjadi perwujudan aplikasi ilmu dan penelitian yang diperoleh di dunia kampus agar dapat dirasakan manfaatnya dalam memecahkan berbagai problematika yang ada di masyarakat. ${ }^{9}$ Kemdiknas (2004) merinci ada empat program kegiatan pengabdian kepada masyarakat . Pertama, Program Vocer yaitu kegiatan pengabdian kepada masyarakat dalam bentuk penerapan dan pengembangan hasil penelitian di Perguruan Tinggi. Kedua, program Vocer Multi Tahun adalah kegiatan pengabdian kepada masyarakat dalam bentuk penerapan dan pengembangan hasil penelitian oleh Perguruan Tinggi yang berlangsung selama tiga tahun karena komoditas yang dihasilkan harus dapat diekspor dan dijual antar pulau. Ketiga, Unit Usaha dan Industri adalah program untuk mendukung upaya pengembangan otonomi Perguruan Tinggi. Keempat, Potensi Masyarakat Sinergi Pemberdayaan merupakan realisasi dari kebijakan pemerintah tentang otonomi daerah dan upaya meningkatkan sinergi pemberdayaan masyarakat yang memerlukan strategi integratif berbagai pihak.

\footnotetext{
${ }^{7}$ Warul Walidin, “Arah Pengembangan Sumberdaya Manusia Dalam Dimensi Pendidikan Islam," Jurnal edukasi: Jurnal Bimbingan Konseling 2, no. 2 (2016): 147-163.

${ }^{8}$ Dhoni Kurniawati, "Manajemen Sumberdaya Manusia Dalam Perspektif Islam Dan Elevansinya Dengan Manajemen Modern," Ijtimaiyya: Jurnal Pengembangan Masyarakat Islam 11, no. 1 (2018): 1940.

${ }^{9}$ Oos M Anwas, "Kuliah Kerja Nyata Tematik Pos Pemberdayaan Keluarga Sebagai Model Pengabdian Masyarakat Di Perguruan Tinggi," Jurnal Pendidikan dan Kebudayaan 17, no. 5 (2011): 565.
} 
Dalam realisasinya, Perguruan Tinggi mengimplementasikan kegiatan pengabdian kepada masyarakat melalui beberapa kegiatan. Kegiatan tersebut antara lain: pendidikan dan pelatihan, pelayanan kepada masyarakat, pengembangan wilayah kaji tindak (action research) dan Kuliah Kerja Nyata (KKN). Kuliah Kerja Nyata merupakan bentuk pengabdian yang melibatkan langsung mahasiswa. Mahasiswa dalam kurun waktu tertentu langsung menyatu dengan masyarakat di lapangan. ${ }^{10} \mathrm{Hal}$ ini yang diiplementasikan oleh dosen dan mahasiswa STIBA Makassar yang terjun dalam program KKN STIBA Makassar di Desa Jonjo mengupayakan berbagai kegiatan keagamaan dalam rangka mempersiapkan SDM masyarakat yang unggul dan religius.

Dalam pelaksanaannya KKN STIBA Makassar di Desa Jonjo dilaksanakan berdasarkan hasil analisis kebutuhan masyarakat Desa sekaligus sebagai upaya sosialisasi dan perkenalan corak kampus STIBA Makassar. Berbagai program yang disusun menjadi upaya ikhtiar bagaimana menciptakan SDM yang berkualitas serta sebagai asset untuk menghadapi perubahan yang begitu dinamis kedepannya. ${ }^{11}$ Dalam implementasinya, KKN STIBA Makassar di Desa Jonjo direalisasikan dalam berbagai bentuk kegiatan keagamaan pembinaan dirosa, tahsin, mengajar TKA/TPA, kultum, khutbah jumat, pelatihan penyelenggaraan jenazah, festival anak sholeh, dan tablig akbar. Hal tersebut dilaksanakan sebagai upaya penyiapan SDM yang unggul dan religious. Masing-masing program tersebut diuraikan sebagai berikut.

\section{Pembinaan dirosa}

Pembinaan dirosa ini diselenggarakan untuk anak-anak dan ibu-ibu, di setiap masjid yang dapat dijangkau oleh mahasiwa KKN STIBA. Kegiatan ini sangat disambut antusias oleh warga setempat. Adapun kendalanya adalah dibutuhkan semangat untuk mengajak warga untuk belajar karena kebanyakan rasa malu sering menghampiri.

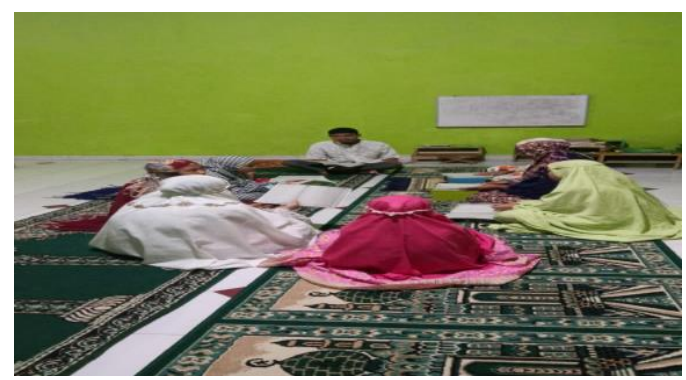

Gambar 2. Pembinaan Dirosa

\footnotetext{
${ }^{10}$ Ibid. p.567

${ }^{11}$ Welfarina Hamer et al., "Menyiapkan Sumber Daya Manusia Unggul Melalui Penanaman Nilai-Nilai Religius Pada Kegiatan Keagamaan Di Desa Pulau Pehawang Kecamatan Marga Punduh,” DEDIKASI: Jurnal Pengabdian Masyarakat 2, no. 1 (2020): 42-54.
} 
WAHATUL MUJTAMA': Jurnal Pengabdian Masyarakat

Vol. 1, No. 2 (2020) : Hal. 116-128

Website: https://journal.stiba.ac.id

\section{Pengajaran Tahsin}

Pelaksanaan tahsin diajarkan kepada ibu-ibu, bapak-bapak dan remaja yang membaca alquran sudah bagus. Kendala yang dihadapi dalm proses tahsin ini adalah kurang buku-buku dan sangat singkat waktu. Namun warga memiliki semangat yang tinggi untuk memperbaiki bacaan alqurannya.

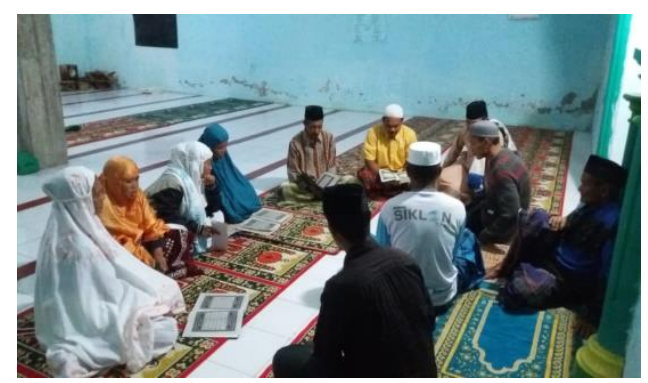

Gambar 3. Pengajaran Tahsin

\section{Program Pengajaran TKA/TPA}

Mengajar TKA/TPA dilaksanakan oleh setiap mahasiswa KKN STIBA Makassar di setiap masjid-mesjid, waktu mengajarnya mulai dari jam dua, setelah ashar, setelah magrib dan setelah isya. Kendala yang dihadapi adalah medan yang pengunungan serta jarak antar masjid dan masjid lainnya cukup berjauhan dengan medan 7 ang terjal. Tetapi karena semangat anak-anak untuk belajar mengaji sehingga memudahkan untuk mengumpulkan anak-anak untuk belajar.

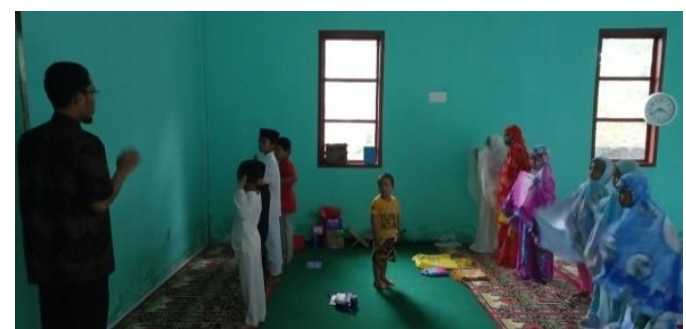

Gambar 4. Program Pengajaran TKA/TPA

\section{Kultum Magrib dan Subuh}

Kegiatan kultum ini dilakukan setiap selesai sholat magrib dan subuh, tapi lebih seringnya dilaksanakan pada subuh hari di masjid terdekat dan isi secara bergantian oleh mahasiswa KKN STIBA Makassar. Kendala dari kegiatan ini adalah jarak untuk tempuh masjid yang saling berjauhan sehingga tidak bisa menjangkau keseluruhan masjid. 


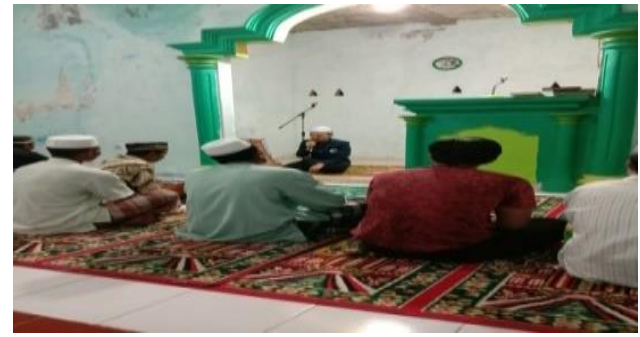

Gambar 5. Kultum Magrib dan Subuh

\section{Khutbah jumat}

Khutbah jumat ini dilaksanakan oleh mahsiswa KKN STIBA Makassar, di setiap sembilan masjid disesuaikan jumlah mahasiswa KKN STIBA. Khutbah jumat termasuk program unggulan mahasiswa KKN Desa Jonjo, dengan membagi 6 mahasiswa dari 9 masjid di Desa Jonjo secara bergilir. Khtubah Jumat ini menjadi sarana pencerahan bagi warga desa Jonjo dalam peningkatan iman dan takwa, karena tak jarang masjid-masjid yang banyak ini tidak semua mampu melaksanakan shalat Jumat secara bersamaan karena keterbatasan khatib Jumat.

Momen jumat ini menjadi kesempatan mahasiswa KKN yang telah menempuh perkuliahan 3,5 tahun di STIBA untuk mengabdi kepada masyarakat dengan memberikan siraman rohani terkait pentingnya tauhid, belajara Islam dan membaca serta memahami Alquran. Mencetak generasi quran mesti dari rumah-rumah yang punya perhatian terhadap Alquran, ada orang tua yang senantiasa mengingatkan anaknya untuk membaca dan mempelajari Alquran.

\section{Pelatihan penyelenggaraan jenazah}

Pelatihan penyelenggaraan jenazah ini laksankan pada tanggal 5 bulan februari, dirangkaikan dengan arisan ibu PKK Desa Jonjo. Menghadirkan dua pemateri dari DPD Kabupaten Gowa. Dan adapun peserta dari ibu-ibu dan bapak-bapak, dibuka oleh bapak kepala Desa Jonjo, dan hadir bersama kami bapak KUA Kecematan Parigi. Adapun kendala dari kegiatan ini, adalah kesulitan untuk menghadirkan peserta, karena kegiatan ini bertepatan dengan kesibukan menanam padi oleh masyarakat, tetapi disisi lain kegiatan ini sangat disambut baik oleh masyarakat.

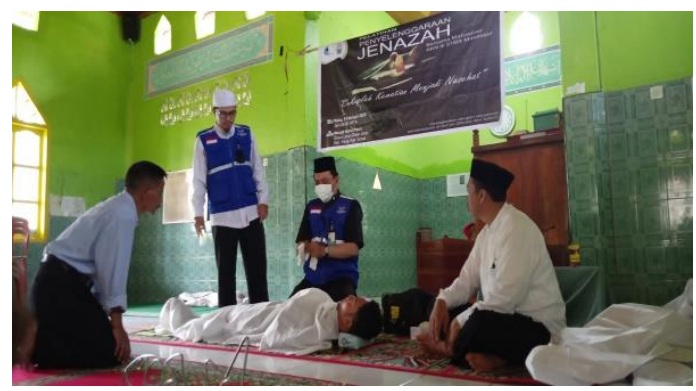

Gambar 7. Pelatihan Penyelenggaraan Jenazah 
WAHATUL MUJTAMA': Jurnal Pengabdian Masyarakat

Vol. 1, No. 2 (2020) : Hal. 116-128

Website: https://journal.stiba.ac.id

\section{Festival anak sholeh}

Kegiatan ini dilaksanakan di Desa Jonjo dan juga di Kecematan Parigi, adapun kegiatan festival di Desa Jonjo pada tanggal 7 sampai 8 Februari, pesertanya berasal dari tiap TKA/TPA yang berbeda yang ada di Desa Jonjo. Program Festival Anak Saleh adalah sarana yang bertujuan untuk menstimulasi minat bakat anak yang secara luas diharapkan dapat meningkatkan kompetensi pengetahuan dasar keislaman, perilaku ibadah, adab, dan akhlak keseharian anak. ${ }^{12}$ Festival anak sholeh di Kecematan Parigi ini dilaksankan pada tanggal 15 sampai 16 . Pesertanya adalah para pemenang di tinggkat Desa. Kegiatan festival anak sholeh ini, sangat disambut antusias oleh anak-anak maupun warga setempat, kendala dari kegiatan ini adalah sulit ana-anak untuk hadir di tempat kegiatan di karenakan jauhnya jarak tempuh dan terkadang harus di jemput, kerena kebanyakan anak-anak hanya tinggal bersama kakek dan nenek yang sudah tua rentah.

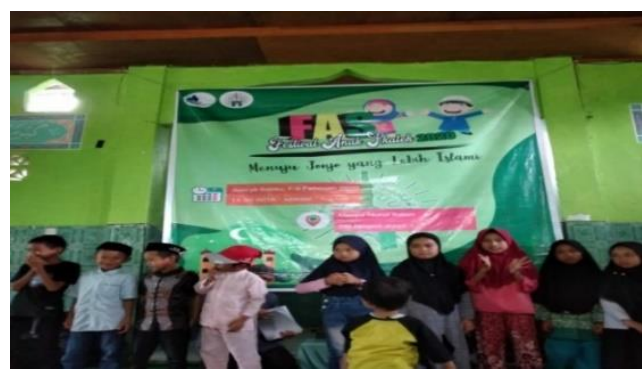

Gambar 8. Festival Anak Sholeh

\section{Tablig akbar}

Adapun kegiatan ini dilaksanakn di Desa Jonjo dan di Kecematan Parigi, sekaligus dirangkaikan dengan penerimaan hadiah pada kegiatan festival anak sholeh. Adapun pemateri tablig akbar di Desa adalh Ustadz Gampang Dadiyono hafizahullah dan tingkat Kecematan pemeteri adalah Ustadz Saifullah Anshor hafizahullah. Adapun kendala dari kegiatan ini adalah kurangnya peserta yang hadir disebabkan bertepatannya dengan kegiatan bertani warga setempat.

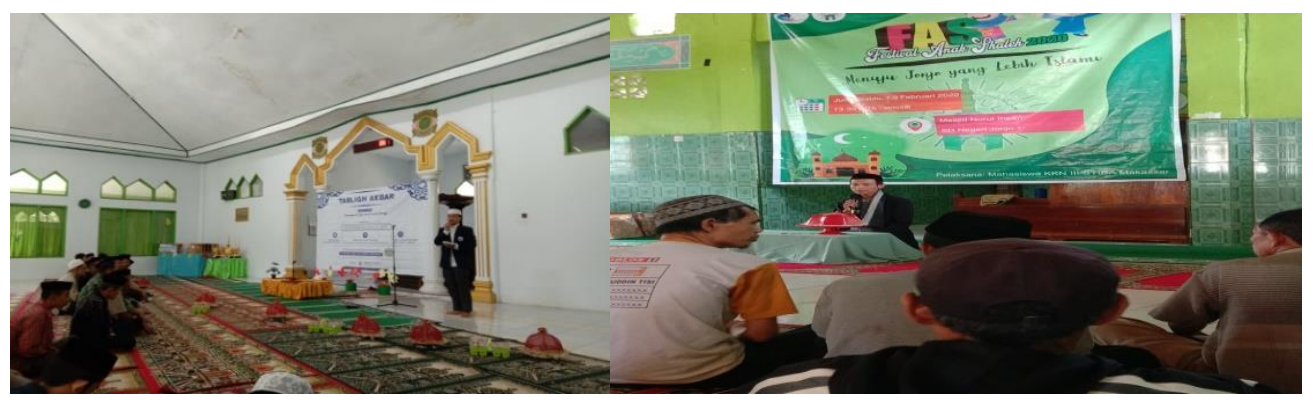

Gambar 9. Tabligh Akbar

\footnotetext{
${ }^{12}$ Aswar Aswar and Rosmita Rosmita, "Festival Anak Saleh Di Desa Leang-Leang Kabupaten Maros," WAHATUL MUJTAMA': Jurnal Pengabdian Masyarakat 1, no. 1 (2020): 54-66. p.65
} 


\section{KESIMPULAN}

Secara umum kegiatan KKN Mahasiswa STIBA Makassar angkatan ke III di Desa Jonjo berjalan dengan baik dan lancar. Seluruh program kerja yang dilaksanakan juga disambut baik dan antusias oleh pemerintah dan masyarakat. Meskipun demikian, terdapat beberapa kendala yang menjadi tantangan dalam proses pelaksanaan program kerja, utamanya aktivitas masyarakat yang mayoritas bekerja sebagai petani di ladang persawahan membuat mahasiswa perlu mengatur waktu pelaksanaan kegiatan lebih banyak dilaksanakan pada malam hari agar masyarakat yang terlibat dapat lebih maksimal. Misalnya saja pelaksanaan taklim rutin yang hanya dimaksimalkan pada waktu magrib dan subuh. Kegiatan setelah magrib dan isya juga banyak dimanfaatkan untuk mengajar tahsin kepada remaja-remaja, yang sangat bersemagat untuk memperbaiki bacaan alquran mereka. Adapun Kegiatan siang hari dan sore hari, digunakan mengajar TKA/TPA diberbagai masjid, yang disambut sangat antusias oleh anak-anak.

Kendala lain yang menjadi tantangan dalam pelaksanaan KKN di desa Jonjo adalah medan yang harus melewati daerah pegunungan dan masyarakat Desa yang tidak mampu berbahasa Indonesia dengan baik. Oleh karena itu, sebagai rekomendasi kedepannya, penempatan mahasiswa KKN perlu diatur dan dibagi sejumlah Dusun yang ada agar mobilitas mahasiswa dapat lebih diminimalisir mengingat mereka harus melewati daerah pegunungan yang terjal dan jauh. Selain itu, mahasiswa KKN yang ditempatkan perlu dilakukan pendataan agar ada perwakilan mahasiswa yang fasih berbahasa masyarakat setempat, dalam hal ini di desa Jonjo adalah bahasa Makassar.

\section{DAFTAR PUSTAKA}

Anwas, Oos M. "Kuliah Kerja Nyata Tematik Pos Pemberdayaan Keluarga Sebagai Model Pengabdian Masyarakat Di Perguruan Tinggi." Jurnal Pendidikan dan Kebudayaan 17, no. 5 (2011): 565.

Aswar, Aswar, and Rosmita Rosmita. "Festival Anak Saleh Di Desa Leang-Leang Kabupaten Maros." WAHATUL MUJTAMA': Jurnal Pengabdian Masyarakat 1, no. 1 (2020): 54-66.

Hamer, Welfarina, Tubagus Ali Rachman Pujakesuma, Anita Lisdiana, Atik Purwasih, Karsiwan Karsiwan, and Wardani Wardani. "Menyiapkan Sumber Daya Manusia Unggul Melalui Penanaman Nilai-Nilai Religius Pada Kegiatan Keagamaan Di Desa Pulau Pehawang Kecamatan Marga Punduh.” DEDIKASI: Jurnal Pengabdian Masyarakat 2, no. 1 (2020): 42-54.

Iskandar, Iskandar, and Muhammad Amirullah. (2020) "Pelaksanaan Dirasah Qur'aniyah Sebagai Upaya Peningkatan Kualitas Baca Al-Qur'an Di Desa Tukamasea Kabupaten Maros." WAHATUL MUJTAMA': Jurnal Pengabdian Masyarakat Vol. 1,no.1: 42-53.

Kurniawati, Dhoni. "Manajemen Sumberdaya Manusia Dalam Perspektif Islam Dan Elevansinya Dengan Manajemen Modern." Ijtimaiyya: Jurnal Pengembangan Masyarakat Islam 11, no. 1 (2018): 19-40. 
WAHATUL MUJTAMA': Jurnal Pengabdian Masyarakat

Vol. 1, No. 2 (2020) : Hal. 116-128

Website: https://journal.stiba.ac.id

Ningrum, Epon. "Pengembangan Sumber Daya Manusia Bidang Pendidikan." Jurnal Geografi Gea 9, no. 1 (2009).

Rofiq, Aunur. Sumber Daya Manusia Berkualitas Perspektif Nabi Syu'aib Dalam AlQur'an. Malang: Lembaga Penelitian dan Pengabdian kepada Masyarakat UIN Maulana Malik Ibrahim, 2011.

Rosidi, Ibnu. "Pengembangan SDM Dalam Pembentukan Karakter Santri Di Lembaga Pengabdian Pada Masyarakat (LPM) Pondok Pesantren Wahid Hasyim Yogyakarta." TA'LIM: Jurnal Studi Pendidikan Islam 1, no. 1 (2018): 106-120.

Satar, Muhammad. "Pengembangan SDM Indonesia Unggul Menghadapi Masyarakat Kompetitif Era Globalisasi." Mimbar: Jurnal Sosial dan Pembangunan 18, no. 4 (2002): 429-442.

Walidin, Warul. "Arah Pengembangan Sumberdaya Manusia Dalam Dimensi Pendidikan Islam.” Jurnal edukasi: Jurnal Bimbingan Konseling 2, no. 2 (2016): 147-163.

Yuniarsih, Tjutju, and Suwatno. Manajemen Sumberdaya Manusia (Teori, Aplikasi Dan Isu Penelitian). Bandung: Alfabeta, 2013. 